\title{
DERrotero DE PLATA EN ATACAMA: GEOGRAFÍA LITERARIA DEL MINERAL DE TRES PUNTAS
}

\author{
Raúl Molina Otárola ${ }^{1}$
}

\section{* Introducción}

Resumen

Los derroteros de minerales constituyen importantes piezas escritas o de la tradición oral que dan cuenta de rutas, caminos, lugares e hitos del paisaje, de la desconocida geografía del desierto de Atacama. Seguidas sus señas conducen a las vetas de valiosos minerales. Para algunos, estos derroteros constituyen un descrédito, meras leyendas, quimeras de la imaginación o metáforas de la riqueza, en sí cuentos falsos e inútiles de encontrar. Sin embargo, algunos derroteros efectivamente permitieron el descubrimiento de importantes minerales de plata en el siglo XIX. Este artículo analiza el derrotero de plata de Tres Portezuelos, de fines del siglo XVIII, que indica cómo llegar a un rico depósito descubierto en 1848. El hallazgo argentífero dio origen al importante mineral de Tres Puntas, ubicado al norte de Copiapó. Se considera al derrotero como geografía literaria del desierto de Atacama, a partir del cual se analizan sus señas y detalles, contrastándolas con el paisaje y el territorio para reconstruir la cartografía contenida en el texto del derrotero, dando cuenta de las alternativas del descubrimiento y el desenlace del mineral de plata de Tres Puntas.

Palabras claves: Tres Portezuelos - minería de la plata - desierto de Atacama - odografía - caminos.

\begin{abstract}
The trails that lead to mines constitute important written texts or oral traditions, which give account of routes, roads, places and landmarks of the unknown geography of the Atacama Desert. When the signs are followed, they can lead to the oreshoots of valuable deposits. For some, these trails are misleading, mere legends, chimeras of the imagination or metaphors of wealth, false and useless stories that lead nowhere. For others, however, they did indeed lead to the discovery of important silver deposits in the nineteenth century. This article analizes the Silver Trail of Tres Portezuelos from the late eighteenth century, a rich deposit that was discovered in 1848 . The finding gave rise to the important mine of Tres Puntas, located north of Copiapó. The itinerary or trail is considered as a literary geography of the Atacama desert, whose signs and details are analyzed, contrasting them with the landscape and the territory to reconstruct the cartography contained in the text of the Trail, revealing alternatives to the discovery and flourishing of the silver mine of Tres Puntas.
\end{abstract}

Key words: Tres Portezuelos - Tres Puntas mine - silver mining - Atacama Desert - trails and paths.

Recibido: julio 2014. Aceptado: octubre 2014.

\section{Los derroteros}

Los derroteros de minerales constituyen notables y crípticas piezas de geografía literaria, en la medida que describen lugares, paisajes y territorios que van siendo dibujados como mapas narrativos, con señas verdaderas, alteradas o imaginadas. Para algunos autores, como Sayago (1874: 376) los derroteros en Atacama son parte de la tradición del relato y la inventiva, surgidos en incidentes casuales que dan con una veta de plata, donde está presente la buena y la mala suerte, las noticias más o menos exageradas con datos ciertos o falseados que forman parte del romance de la industria minera. Para otros será "...la cartilla en que el minero aprende su destino i lee en ella como si sus hojas invisibles fueran pájinas en Jénesis subterráneo" (Vicuña Mackenna 1882: 255), o son definidos como "planos descriptivos que muestran la ubicación de minas" (Bowman 1924: 177). Sostengo que los derroteros son mucho más que estas alegóricas y lacónicas definiciones. En los derroteros se describe la ruta a seguir usando la toponimia, los rumbos, las distancias, los accidentes geográficos, las señas del paisaje, las huellas humanas y la descripción de las características del sitio donde se encuentra la veta, todos aspectos que se deben observar para acceder a la riqueza minera. El derrotero es un relato que bien leído y descifrado lleva hasta las coordenadas de minerales de plata, situados en lugares discretos de la inmensa y desconocida geografía del desierto de Atacama. Los derroteros deben ser examinados tanto en el papel como en el territorio, en una operación de contraste entre la literatura y la geografía. Este diálogo entre texto, lugar, paisaje y territorio busca arribar a la veta argentífera, muchas veces escudriñada

\footnotetext{
1 Centro de Investigaciones del Hombre en el Desierto (CIHDE). Av. General Velásquez 1775, Arica, CP 1000000, Chile. Email: raul17molina@gmail.com
} 
pero no encontrada, pues los derroteros no están exentos de alteraciones imaginarias, realizadas a propósito o deformadas por la transmisión oral, factores que estropean el rumbo y la ruta de quien se anime a recorrer el desierto en busca del filón de plata. Debido a estas frustraciones y dificultades, algunos autores consideran al derrotero con demérito: "...son alucinaciones como lo es la búsqueda de tesoros ocultos en los escritores de ficciones. En el desierto abundan los 'cerros encantados' y los 'cerros de plata', dice Bowman (1924: 117).

Pese a la sospecha de su veracidad y utilidad como carta de navegación, los derroteros alcanzaron gran notoriedad histórica en Copiapó y todo Atacama. Los primeros aparecen con la llegada de los españoles (Vicuña Mackenna 1882), pero muchos de ellos surgen a fines del período colonial y algunos se transforman en verdaderas obsesiones y leyendas. Encontrar la veta prometida era el sueño de la riqueza rápida, del cambio de destino o un modo de acrecentar el poder. La búsqueda de minerales de plata se desarrolló con o sin derrotero previo, a través de todo el siglo XIX, momento en el cual los cateadores del desierto trajinaron con insistencia su geografía, en busca del lugar que ocultaba el mineral y la riqueza. Muchos de los intentos dieron resultados, generando numerosos enclaves en Atacama, y los más importantes fueron asociados a conocidos derroteros.

Los derroteros de minerales en su mayor número fueron generados por arrieros, cazadores y pastores, mestizos e indígenas, también por algunos españoles, que se adentraron y recorrieron el desierto de Atacama (San Román 1896; Gigoux 1927). Sus señas y descripciones literarias se transformaron en verdaderos laberintos crípticos para quienes desconocían la geografía del desierto, y el arte y oficio del cateador. El ocultamiento de la veta fue un temprano aprendizaje de los versados en el desierto. Escondieron las coordenadas de esos lugares ignotos y legendarios que contenían la riqueza minera. Durante los siglos de colonialismo hispano las vetas fueron guardadas discretamente por los indígenas, especialmente los del Pueblo de Indios de San Fernando de Copiapó, poniéndolas fuera del conocimiento y de la codicia de otros, evitando así la presión y la persecución, e incluso la tortura para arrancar la confesión de la localización de la supuesta mina de plata (Sayago 1874). Para el indígena conocer el paradero de minerales nobles no sólo pudo ser una fuente de riqueza y bienestar, sino también una condena.

Durante el siglo XIX se conocen numerosos derroteros de minerales, algunos recordados y reproducidos verbalmente desde el período colonial, cuyas señas sirvieron a los buscadores de minerales para encaminarse más de una vez a las entrañas del desierto de Atacama. Entre los derroteros más destacados o conocidos se encuentran el de "Los Candeleros", de "Los Aragoneses", del "Chango Aracena", que atizaron constantemente el fuego y el fulgor de nuevas y fracasadas expediciones mineras. Estas empresas de exploración, a pesar de los constantes intentos de búsqueda y de las incontables horadaciones del desierto, no lograron encontrar las vetas, lo que obligó a insistir en la búsqueda o seguir con nuevas exploraciones de minerales de plata. Si los derroteros no dieron frutos, no sólo se debió a que contenían datos deformados o inventados, sino también porque describían, muchas veces, una geografía ajena y desconocida a quien pretendía encontrarlos. Es paradójico que algunos descubrimientos de minerales por otras circunstancias, si se compara el lugar con la descripción realizada en el derrotero, éstas tienden a coincidir. Por ello, en este trabajo se postula que algunos derroteros corresponden a la localización efectiva de importantes minerales que se descubren en el siglo XIX. Para fundamentar esta aproximación se realiza el estudio del derrotero Tres Portezuelos, dado por el arriero Fermín Guerra a fines del siglo XVIII. Su hallazgo origina uno de los principales minerales de plata del desierto de Atacama, a mediados del siglo XIX. El derrotero de Tres Portezuelos, se analiza como texto, destacando los lugares y paisajes contenidos en su relato, las distancias, los rumbos, la toponimia, las marcas humanas, las señas y accidentes del terreno, que constituyen los hitos de la ruta que direccionan el camino hasta el lugar de la veta. Todos estos aspectos literarios y geográficos permiten considerar a los derroteros como cartas de navegación y mapas virtuales, que ayudaron a descubrir la riqueza minera en la intrincada geografía del desierto de Atacama.

\section{Geografía literaria}

Los derroteros actúan como descripciones literarias de una geografía mayormente desconocida al lector, y a la vez funcionan como descripción de la ruta que lleva a la riqueza. En los siglos en que estuvieron en uso, su po- 
der de seducción aumentó al mezclarse con otros relatos quiméricos, como las leyendas de entierros de tesoros, el relato de "la mina del indio", de los "cerros arenosos" o el más clásico derrotero que buscaba en cada lugar el "tesoro del Inca" (Vicuña Mackenna 1882). Estas leyendas de riquezas provocaron muchas veces la devastación y el saqueo de numerosos sitios arqueológicos del desierto. ${ }^{2}$

Los derroteros como piezas de geografía literaria son un intento de narrar territorios con descripciones que dibujan sistemáticamente mapas, describen rutas que unen lugares y atraviesan paisajes que llevan sucesivamente, y a medida que se avanza, a localizar el lugar que contiene la riqueza mineral. En sí, el derrotero tiene la pretensión de ser un mapa literario fidedigno, que contiene escritas señas contrastables en el paisaje, ordenadas sistemáticamente a través de parajes sucesivos por los cuales atraviesa la ruta que lleva a la veta argentífera. Construyen imágenes indiscutibles del lugar, que unen la percepción de la persona con el entorno (Hiernaux y Lindón 2012), señales de la geografía, que dan certeza y veracidad a la ruta seguida.

Los derroteros son parte, pero a la vez se distinguen de otras geografías literarias, en cuanto pretenden describir un itinerario como crónica verdadera y fidedigna. Esta pretensión marca algunas diferencias con otras descripciones literarias de lugares, paisajes o territorios, que incluyen preferentemente la subjetividad del espacio vivido y la percepción de los lugares (Tuan 2007). Guarda a su vez distancia con aquellas narraciones sobre experiencias y relaciones sociales en el paisaje, descritas en la crónica, el cuento y la novela (Furlani y Gutiérrez 1990; SabateLlobera 2007; Boira 2012). Sin embargo, los derroteros no siempre son piezas con presunciones de exactitud. A veces incluyen anotaciones alteradas o ficticias, que ex profeso, esconden la riqueza minera. ${ }^{3}$ Las transformacio-

2 La labor de búsqueda de la plata y el oro en los terrenos del despoblado de Atacama a través de derroteros es comparable o evoca la contemporánea arqueología subacuática y su búsqueda de tesoros en los fondos marinos o se puede comparar con aquella dedicada a localizar fortunas escondidas cerca de playas, acantilados o islas, atribuidos a corsarios, como ocurrió en Juan Fernández recientemente.

3 El caso más típico es el llamado "Derrotero del Chango Aracena" que fue buscado por numerosas expediciones (Philippi 1856), pero no hallada la veta. Recientemente un estudio señala haberlo ubicado en el sector de Vaca Muerta en el desierto de Atacama (Pedersen 2012). nes en los contenidos narrativos de los derroteros, tienen cierta cercanía con la geografía imaginaria, entendiendo por ella a las diversas aproximaciones que adquiere el concepto en las últimas décadas (Zusman 2013), pero usado aquí en el sentido que la narrativa perturbada construye cartografías y paisajes que no pueden llevar hasta las coordenadas de la riqueza minera (Molina 2010). Algunos derroteros se pueden asemejar con imaginarios geográficos que hablan de lugares inventados o creados, pero que no necesariamente tienen un sitio exacto en el territorio, como El Dorado, la Atlántida y tantos otros (Eco 2013). Así el derrotero buscado y no hallado por generaciones podría mutar y trasladarse al espacio de este tipo de geografía imaginaria. Si fuese sólo literatura sin ánimo de encontrar un filón de plata, estaría en el campo de la imaginación geográfica, de la creación de espacios ficticios donde transcurre una historia. Esta experiencia imaginada la podríamos encontrar en la literatura del cuento y la novela. ${ }^{4}$ Se debe considerar, además, que en muchas ocasiones los derroteros van trasmutando los componentes primigenios, amalgamándose con concepciones europeas o con los mitos y leyendas indígenas (Magasich y De Beer 2001; Bartra 2004; Rojas Mix 2006; Bruna 2007). El derrotero puede así transformarse en geografía imaginada o en imaginario geográfico, cuando lo buscado no es hallado y al relato se le asigna un carácter mítico o de leyenda, o bien cuando su construcción se independiza de la pretensión de ser una cartografía contrastable fidedignamente en el territorio.

La geografía literaria de un derrotero, en el sentido de relato y mapa narrativo con pretensiones de credibilidad, es una invitación al viaje, a avanzar por el camino trazado en busca del mineral, pero no es el viaje. La geografía del viaje es el resultado de la búsqueda del derrotero, el relato de la experiencia vivida y contada en primera persona como lo hará José Joaquín Vallejo en 1842 buscando el derrotero de Tres Portezuelos- que construye imágenes del lugar cargadas de la experiencia individual (García y Cerarols 2012). En tanto, la información del derrotero siempre sigue inalterada y estará en la mayoría de las

4 La literatura del norte de Chile ha dado pocos cuentos acerca de los derroteros. Uno de ellos es "Recuerdo del Norte i Derrotero del Cenizal" un cuento escrito por Omer Emeth en 1908, del cual se reprodujeron 100 ejemplares, y "Derroteros y Cangalla" de Mario Bahamonde, un clásico publicado por Editorial Nascimento en 1978 . 
oportunidades contada en tercera persona y referida al camino, al paisaje, los accidentes del terreno, y las señas del mineral. Sin embargo, el derrotero al momento que entrega las instrucciones y señas, siempre está promoviendo el viaje, el desplazamiento, e invitando a vivir la experiencia de encontrar la veta.

El derrotero no posee aspectos prodigiosos que lo pudiesen asemejar con los viajes medievales y la búsqueda de "la maravilla", que son relatos de fenómenos extraordinarios de la naturaleza (Le Goff 1996). Más bien el derrotero propone, aunque muchas veces no lo logre, establecer una relación y correspondencia entre texto y territorio, entre narración y geografía. Por ello, el derrotero está más cerca de una geografía de los itinerarios, de los desplazamientos, de las rutas, de los caminos, pero se diferencia en que presenta un propósito único: el fin buscado es la riqueza. Los derroteros constituyen piezas que precisan el domicilio de las vetas de minerales, escribiendo una correcta, ordenada y sucesiva relación de accidentes geográficos que instruyen sobre el desplazamiento y guían en el rumbo. Una buena descripción literaria de la geografía del derrotero tiene más probabilidades de ayudar a encontrar la riqueza mineral prometida.

El análisis de los derroteros precisa de la identificación de las partes que lo constituyen. Del examen de estas piezas se releva información particular y local, que debe considerarse parte de un encadenamiento. Se trata de una deconstrucción que analiza las partes en su sentido, significado y contenido, pero que vuelve a ensamblarse al relato para dar una comprensión correcta del camino, que puede llevar al objetivo final, la veta o filón del mineral de plata. Por ello, la geografía literaria de un derrotero es una cartografía de la búsqueda del mineral, a través de lugares sucesivos, desplazándose en el paisaje y en el territorio. La geografía literaria del derrotero dialoga, navega y transcurre entre una geografía de lo imaginario y una geografía del viaje, pero su fin es cumplir el itinerario descrito, para el hallazgo del filón de plata.

En virtud de lo expresado se estudia el derrotero de plata de Tres Portezuelos. Se sostiene que éste efectivamente entrega señales y rumbos verificables en el territorio y en el paisaje, que llevan a la ubicación de las vetas de plata de uno de los mayores y más importantes minerales argentíferos descubierto en el desierto de Atacama en el siglo
XIX, llamado "Tres Puntas". Se estudia el derrotero como texto que nombra lógica y consecutivamente lugares en la geografía, instruyendo cómo avanzar en el desierto de Atacama, un lugar desconocido para muchos y nunca sacralizado (Vicuña 1995).

\section{* Derrotero de Tres Portezuelos}

El 22 de febrero de 1842, el periodista copiapino José Joaquín Vallejo, de seudónimo Jotabeche, publica en el diario El Mercurio el artículo denominado "El Derrotero de la veta de los Tres Portezuelos", conteniendo el testamento del arriero Fermín Guerra (Vallejo 1970: 87). La confesión fue hecha en el lecho de muerte al párroco Nicolás Prieto, de Copiapó, a fines del siglo XVIII. A éste le confidenció los detalles de la ruta que desde esta ciudad se debía seguir para alcanzar la veta de plata escondida en el desierto de Atacama.

Abraham König publica en el siglo XIX los escritos de José Joaquín Vallejo, y comenta que Jotabeche con el testamento en mano, intentó seguir el derrotero de Fermín Guerra. Señala que Vallejo en su crónica "hace una descripción minuciosa i grafica del chasco que se llevó en compañía de otros amigos por dar crédito a las mentiras ilusiones de vetas prodigiosas e imaginarias" (König 1878: XXI). El descrédito a los derroteros de minerales, será muy común entre personas desconocedoras de la minería y de la geografía del desierto. El escritor armó su expedición en busca de la veta de plata y logró avanzar un largo camino siguiendo el derrotero, pero su empeño fue vencido por el desierto debido a la improvisada expedición y al cansancio de los días.

El derrotero transcrito y publicado por Jotabeche señala lo siguiente:

"Derrotero que en artículo de muerte descubrió el burrero Fermín Guerra a su confesor D. Nicolás Prieto, cura indigno de esta Parroquia. Andarás como doce leguas por la Quebrada de Paipote $i$ tomando por un cajón que tiene en la entrada dos algarrobos mui gruesos, andarás hasta un portezuelo que tiene muchos cardones $i$ luego subirás el portezuelo i al otro lado, después de unas quebradillas encontraras una aguada que tiene un chepical mui grande, i luego andarás a la izquierda por un llano que tiene mucha varilla, i después de andar hasta unas piedras mui grandes que están 
en medio del llano, andarás a la derecha siguiendo un zanjón hasta dar con unas lomas de arena. Desde estas lomas descubrirás, mirando al lado del mar, un cordón de cerros $i$ andarás hasta llegar al cordón dirigiéndote derecho a unos tres portezuelos que se ven desde muy lejos. En el de tu izquierda, que subirás, encontraras una veta que la rumbearas a la derecha hasta dar con un picado de una vara de hondura y poco más allá está un crestón de plomería en el cual hai una cruz hecha con un cuchillo. Luego que encuentres esta riqueza mandarás decir una misa cantada todos los viernes del año por el alma del descubridor Fermín Guerra, pagándosela al cura Prieto a razón de veinte pesos cada una, quien hará la limosna de echar a lo último un responso. I te advierto que si no lo haces asi te irá mal. Se advierte que Guerra descubrió la veta, porque se perdió viniendo del Chañaral u del Pueblo/hundido, pero después volvió allá, i trajo piedras que en articulo de muerte las ha mostrado a dicho cura, i servirán para su entierro. Al pie del portezuelo del medio hai una buena aguada donde es mui fácil cazar huanacos i burros chúcaros.- Copiapó, junio 4 de 1792.- A ruego de Fermín Guerra por no saber- Nicolás Prieto" (Vallejo 1878: 32-33).

Para el historiador Sayago de Copiapó, la fecha del testamento tendría una evidente inexactitud en el año "...si es que la fecha anotada por Jotabeche no ha sido equivocada. Y ella consiste en que don Juan Nicolás Prieto y Escobar estuvo al frente de la parroquia desde 1756 hasta enero de 1787 [...] En 1792, el curato estaba interinamente a cargo del bachiller don Vicente Mercado" (Sayago 1874:392). El desfase puede ser un error de transcripción paleográfica o de imprenta, pero la diferencia temporal no altera el contenido y la probable veracidad de esta hoja de ruta, carta de navegación, derrotero minero y mapa literario. Es notable, además, que el derrotero contenga inserta una solicitud de pago y retribución que aumentaría la seriedad de éste.

El propio José Joaquín Vallejo intentó encontrar el mineral de plata y preparó una expedición, al parecer no muy bien montada: "...por mi parte me determiné con unas esperanzas del porte de una torre para encontrar el derrotero. Se fijó nuestra salida, i cuando llegó el plazo, emprendimos la marcha. Llevamos mulas de tiro, dos cargas de víveres $\mathrm{i}$ de agua, i dos criados algo prácticos del despoblado en que íbamos a andar. Creímos que nos sería mui útil una brújula, i también fue con nosotros" (Vallejo 1878: 33).

Los expedicionarios salieron caminando y se adentraron por la Quebrada de Paipote. De noche alcanzaron hasta la encajonada quebrada donde estaban los viejos algarrobos. Lo recorrido era inequívoco, correspondía a la geografía y paisaje de lo señalado en el derrotero: "No es decible el gusto que esperimentamos al hallar este primer signo de la fidelidad del derrotero. iVamos bien! fue nuestra esclamación jeneral" (Vallejo 1878: 33). Durante la noche durmieron bajo uno de los árboles nombrados en el derrotero de Fermín Guerra. Al segundo día, siguieron camino por el "cajón" descrito en el derrotero, alcanzaron el portezuelo de los cardones y en la tarde llegaron a la aguada del chepical, "...donde resucitaron nuestras mulas que ya perecían de hambre i de sed" (Vallejo 1878: 33). Al tercer día, siguen el derrotero y comprueban que es un mapa literario fidedigno cuyas señas y descripciones coinciden con el paisaje. Ingresan en el llano de la izquierda " donde notamos con placer la varilla que el papel indicaba, i después de seguirlo por un mismo rumbo hasta las dos de la tarde, vimos las piedras grandes i nos apeamos al pie de ellas. Mui cerca aparecía el zanjón que debíamos seguir sobre la derecha". Ese día no lograron divisar las "lomas de arena", el siguiente hito geográfico del derrotero, pero Vallejo confiesa: "En verdad que el derrotero hasta entonces no nos engañaba". Sin embargo, el viaje comenzaba a hacer estragos. Les agobiaba el desierto, ese espacio amplio, seco y prístino: “...era mui fácil extraviarse; un cansancio terrible nos acongojaba en estremo. Los animales no podían casi tenerse en pie, era necesario, en fin, suspender la marcha aunque la luna alumbraba bastante... no es posible hallarse tranquilo en medio de un yermo espantoso, sin amparo, sin refujio i sin esperanzas de volver a la sociedad, faltando los frájiles auxilios que uno ve aniquilarse, sin cesar, a su alrededor. Maldije mil veces al derrotero i mi locura" (Vallejo 1878: 34). Esa tercera noche, la decisión de los buscadores de las vetas de plata, fue: "Antes de acostarnos nos comprometimos a seguir adelante hasta las doce del otro día, hora en que debíamos retroceder, si no encontrábamos las lomas de arena" (Vallejo 1878: 34). Al cuarto día siguieron las señas del derrotero, y al medio día "...mui a lo lejos i al frente veíamos dibujado el perfil de unas alturas que no podían ser sino las lomas buscadas. iCómo detenernos! Tal vez allí cerca estarían el cordón de cerros, los portezuelos, la veta i el agua" (Vallejo 1878: 34). Los buscadores del derrotero continúan el camino que se les alarga, las dos horas calculadas para llegar a las lomas de arena se transfor- 
man en cinco. Desde la cumbre de las lomas de arena otean el horizonte en la dirección de los portezuelos que indica el derrotero y verifican las últimas señales que quedaban por avanzar. Pero fue el momento de renunciar a seguir el camino, lo que parecía cerca, se alejaba, el cansancio y la distancia derrotan la fe del grupo de improvisados expedicionarios: “.... un tiempo se dirijieron nuestros ojos hacia el lado del mar, i a un tiempo también nos oímos mutuamente un grito de desesperación i de despecho. iSólo un mar de arena se nos presenta a la vista, mar de arena que por todas partes formaba horizonte...! Sin embargo, después de fijarnos un largo rato, creímos descubrir, a una distancia incalculable, cierta sombra o mancha que pegada a la tierra ofrecía un color más oscuro que el del cielo, la cual si no era el cordón de cerro de los tres portezuelos, debía formar uno de los linderos del infierno. Porque, ¿qué tendría de estraño que el infierno se hallase en esas rejiones? -Nos volvemos. Yo no doi un paso adelante. El tal Guerra, el demonio i el cura Prieto formaron ese maldito papel para burlarse de nosotros" (Vallejo 1878: 35) La empresa de búsqueda fue abandonada para regresar maltrechos a Copiapó. Pero las recriminaciones finales no invalidaron el derrotero que presentaba hasta donde lograron avanzar, señas ciertas y reconocibles en el paisaje y la geografía.

\section{Geografía literaria del derrotero de Tres Portezuelos}

Intento ahora un ejercicio de geografía literaria, consistente en llevar las señas e hitos del derrotero de Tres Portezuelos, al paisaje y el territorio del desierto de Atacama. Este ejercicio permitirá construir una cartografía aproximada de la ruta al mineral. Para ello, acompaño la lectura con una búsqueda del sentido de cada concepto o accidente geográfico nombrado en el derrotero, como hitos observables en el paisaje, en la movilidad y en la dirección de ésta. Posteriormente, teniendo en cuenta la crónica de José Joaquín Vallejo, el conocimiento propio del territorio y la cartografía actual, intento construir el probable mapa a Tres Portezuelos. ${ }^{5}$

5 El autor ha recorrido la zona en sus diversas investigaciones sobre el Desierto de Atacama. En 2005-2007 fue investigador responsable del Proyecto Fondecyt $N^{\circ}$ 1040290, "El Despoblado de Atacama: espacios, rutas, articulaciones y poblamiento en la re-
El primer dato geográfico que nombra el derrotero es la "Quebrada de Paipote". Ésta desemboca en el valle del río Copiapó, a unos ocho kilómetros al este de la ciudad del mismo nombre. Es una quebrada ancha de base plana que va subiendo lentamente hacia la cordillera en dirección noreste. Ignacio Domeyko en su visita en 1850 a Copiapó describe la Quebrada de Paipote: “...orientada hacia el norte, está sobre la ruta que conduce al desierto de Atacama. Hablando en propiedad es aquí donde comienza este desierto" (Domeyko 1978: 443). Justamente por esta puerta al desierto o despoblado, el derrotero entrega las primeras instrucciones: "Andarás como doce leguas por la Quebrada de Paipote". En este sentido la distancia es aproximada, tanto en la redacción -"como"-, y en la longitud. La legua según usos, regiones y países tiene diversas medidas que van entre 4 y $7 \mathrm{~km}$. La legua castellana equivalente a 5000 varas castellanas, a 2,6 millas romanas o 4,19 km. Se uniformó en el siglo XVI, siendo definida como "medida itineraria, variable según los países o regiones, definida por el camino que regularmente se anda en una hora, y que en el antiguo sistema español equivale a 5572,7 m" (RAE 2001). En este caso las 12 leguas, medidas en las antiguas leguas castellanas, corresponderían a $50,28 \mathrm{~km}$, y en legua uniformada, aproximadamente a $66,8 \mathrm{~km}$. El derrotero de Tres Portezuelos indica que recorridas las "doce leguas", se debe tomar "un cajón que tiene en la entrada dos algarrobos mui gruesos". En efecto, como vimos, José Joaquín Vallejo no tiene dificultad en encontrar los dos algarrobos e incluso duerme bajo uno de ellos. Éstos se encuentran según el derrotero ubicados en la intersección del "cajón" -quebrada angosta con paredes rocosas pronunciadas- con la Quebrada de Paipote. Este lugar sería de fácil observación por encontrarse a la vista desde el ancho cauce de la quebrada. Para reconocer a cuál quebrada corresponde este "cajón", analicemos las demás señales del derrotero: "andarás - por el cajón- hasta un portezuelo que tiene muchos cardones i luego subirás el portezuelo i al otro lado, después de unas quebradillas encontraras una aguada que tiene un chepical mui grande, i luego andarás a la izquierda por un llano que tiene mucha varilla". Esta descripción de geografía literaria es abundante en datos. Se trata de una quebrada angosta que tiene en la confluencia con la Quebrada

\footnotetext{
gión Circumpuneña". Durante su desarrollo visitó la mayoría de los lugares que son nombrados en el derrotero de Fermín Guerra, y este artículo tiene su antecedentes en dicho proyecto.
} 
Paipote "dos algarrobos mui viejos" y en el otro costado un "chepical", que da paso a otra formación geográfica, un "llano", terreno plano y extenso, también conocido como pampa en el norte de Chile. ${ }^{6}$ Por tanto, tenemos un cajón que, recorrido entre los dos puntos señalados, pasa por un "portezuelo con cardones" (usado como genérico de cactus), luego aparecen "quebradillas" al costado del mismo cajón y se llega a una "aguada", hito fundamental del desierto, "que tiene un chepical muy grande". Ésta es una formación vegetacional, una vega con pasto y aguas superficiales. Chepical es un localismo chileno que señala la existencia de una importante superficie de chépica, un pasto duro o grama que tiene una aguada (RAE 2001). El "chepical", se extiende desde la quebrada o cajón y continúa en el "llano". Es decir, al final del "chepical" ya se está en el llano. El único accidente geográfico que presenta esta característica es la denominada Quebrada Puquios -voz quechua que significa fuente de agua clara-.7 La quebrada Puquios o "cajón", tiene en su parte norte una larga vega ("chepical") que actualmente posee una extensión de casi dos kilómetros de longitud, y da acceso al Llano de Varas. Este llano es un plano inclinado que sube lentamente hacia el norte, formando una suave cuenca que recibe las escasas precipitaciones ocasionales en esta parte del desierto y que luego escurren subterráneamente para formar en la parte más deprimida el "chepical" y el afloramiento de la aguada. ${ }^{8}$ El "cajón" - quebrada Puquios-, tienen su parte sur, donde junta con la Quebra-

6 Es muy sugerente que los conceptos llano y pampa significando lo mismo, su uso está diferenciado geográficamente en el desierto de Atacama. La quebrada del Salado y su río de la Sal sirven de deslinde. Al sur de éste se usa el topónimo llano para referirse a los terrenos planos y espaciosos del desierto separados por cordones de cerros. Entre estos llanos están el de Chulo, de Varas, de Humitos, de Inca de Oro, de San Pedro, entre otros. Mientras tanto al norte del río Salado el vocablo quechua pampa es el más común, con excepción del llano de San Juan cerca del mineral El Salvador. Esto podría deberse a que en la colonia y primeros años de la república este río Salado se señalaba como límite entre Chile y Bolivia.

7 "El puquío... es voz genuinamente quichua i significa fuente de agua clara, límpida, distinta de la vertiente ordinaria i del manantial por cuanto su manera de existencia es una superficie llana i no en terreno inclinado, brotando el agua a poca hondura, de orificio profundo, en forma de pozo o estanque de estrechas dimensiones" (San Román 1896: 81, tomo III)

8 Véase Carta geográfica Carrera Pinto 2700-6945, escala 1: 50.000 del Instituto Geográfico Militar (IGM). da de Paipote, a los "dos algarrobos" y el extremo norte al "chepical". Esta quebrada es descrita en el siglo XIX: "El nombre de 'Quebrada de Puquios' se da a una simple grieta tortuosa, de tres kilómetros de estensión, altísimas paredes i en partes sin el necesario ancho para dejar cruzarse dos carretas" (San Román 1879: 9, Tomo I). Desde la confluencia de la Quebrada de Puquios o "cajón" con la Quebrada de Paipote, la distancia hasta al río Copiapó es aproximadamente de $52 \mathrm{~km}$ y de $60 \mathrm{~km}$ hasta la ciudad de Copiapó. Este trayecto estaría dentro del rango aproximado de las 12 leguas indicadas en el derrotero.?

Saliendo por el norte de la quebrada de Puquios o "cajón", en el lugar de "chepical" -que también llevará más tarde el nombre de "Vegas de Puquios" (San Román 1896: 87, Tomo III), ${ }^{10}$ el derrotero da nuevas instrucciones de navegación: “...i luego andarás a la izquierda por un llano que tiene mucha varilla, i después de andar hasta unas piedras mui grandes que están en medio del llano, andarás a la derecha siguiendo un zanjón hasta dar con unas lomas de arena". Considerando que la quebrada de Puquios o "cajón" tiene un rumbo norte-sur, en su salida norte, desde el "chepical" se debía tomar a la izquierda, es decir, un rumbo aproximado nor-noroeste, para seguir camino "por un llano que tiene mucha varilla". La varilla (Adesmia deserticola o A.t.) es una especie vegetal adaptada a condiciones de aridez, usada como combustible y en ocasiones como forraje de animales ${ }^{11}$ (Niemeyer 1981; Molina et al. 2001). Este

9 La confluencia de la Quebrada de Puquios o "cajón" en el derrotero, con la Quebrada de Paipote, en la década de 1870 ya contaba con un establecimiento minero, con un pequeño poblado, donde llegaba la estación terminal de ferrocarril de Copiapó. Puquios es descrito en 1885 por Federico Philippi, hijo de Rodulfo: "Puquios tiene una sola calle, donde hay unas cincuenta casas; la estación es grande y el lugar tiene cierta importancia por una planta de amalgación" (Philippi, F. 1975: 182-183).

10 "Vegas de Puquios.- en el desaguadero del antiguo lago cuyo resto por último es la cuenca hoi llamada llano de Varas, en la especie de embudo por donde el agua se precipitó en rápido torrente al través de una grieta para vaciarse en la quebrada de Paipote, hai vegas de relativa estensión que han prestado los más valiosos servicios a las industrias mineras i metalúrgicas" (San Román 1896: 135, tomo III).

11 En el trabajo de campo con comunidades collas he recogido el siguiente testimonio: "La varilla se da por alturas, por ejemplo la varilla brava o varilla chica se da de los 1800 a los $3500 \mathrm{~m}$, más o menos (En el Llano de Varas se da entre los 1400 y 1600 m); la 


\begin{tabular}{|c|c|c|}
\hline Hito geográfico & Distancia y/o rumbo & Observaciones \\
\hline "Quebrada Paipote" & Andarás 12 leguas. & Desde Copiapó o la entrada de la Quebrada de Paipote. \\
\hline “Cajón” & Ingresar y recorrerlo hasta cruzarlo. & $\begin{array}{l}\text { Quebrada angosta de paredes pronunciadas. Se trata de la actual } \\
\text { quebrada de Puquios. }\end{array}$ \\
\hline "Dos algarrobos muy viejos" & & $\begin{array}{l}\text { Está en la confluencia de la Quebrada de Paipote con el inicio de la } \\
\text { quebrada encajonada (Puquios). }\end{array}$ \\
\hline "Cajón - Portezuelo" & $\begin{array}{l}\text { Andarás hasta este lugar. } \\
\text { Subir al portezuelo. }\end{array}$ & Posiblemente está en el interior del cajón. "Tiene muchos cardones". \\
\hline “Cajón - Quebradillas” & Después de estas quebradillas se encuentra una aguada. & \\
\hline "Aguada y Chepical muy grande" & & Se trata de una gran vega con una aguada llamada también puquio. \\
\hline "Llano con muchas varillas" & Andar a la izquierda, hasta unas piedras muy grandes. & $\begin{array}{l}\text { Se trata de unas planicies con vegetación leñosa. Actual Llano de } \\
\text { Varas. }\end{array}$ \\
\hline "Piedras muy grandes" & Desde aquí andar a la derecha siguiendo un zanjón. & Las piedras grandes están en medio del Llano de Varas. \\
\hline “Zanjón” & Seguirlo hasta dar con unas lomas de arena. & Van en dirección Sur a Norte. \\
\hline "Lomas de arena" & $\begin{array}{l}\text { Mirar al lado del mar, para descubrir un cordón de } \\
\text { cerros. } \\
\text { Andar derecho hasta los Tres Portezuelos, que se ven } \\
\text { desde muy lejos. }\end{array}$ & $\begin{array}{l}\text { Desde estas lomas de arena se aprecia al final un cordón de cerros } \\
\text { que corresponde a Tres Puntas. }\end{array}$ \\
\hline "Tres Portezuelos" & & Lugar de veta de plata. \\
\hline $\begin{array}{l}\text { "Portezuelo de la izquierda" } \\
\text { "Veta" } \\
\text { "Crestón de plomería" } \\
\text { "Cruz hecha con cuchillo". }\end{array}$ & $\begin{array}{l}\text { El portezuelo debes subir. } \\
\text { Encontraras una veta que la rumbearás a la derecha } \\
\text { hasta dar con un picado de una vara de hondura. } \\
\text { Más allá está un crestón de plomería. }\end{array}$ & Sobre el crestón una cruz hecha con un cuchillo. \\
\hline "Portezuelo del Medio" & Al pie hay una buena aguada. & Es muy fácil cazar guanacos y burros chúcaros. \\
\hline
\end{tabular}

Tabla 1. Componentes geográficos del derrotero de Tres Portezuelos.

"llano" es el actualmente denominado Llano de Varas, cuyo nombre "de Varas" es dado por la presencia de la Adesmia deserticola o varilla. El Llano de Varas tiene un ancho de unos seis kilómetros promedio, ${ }^{12}$ por él y en dirección nor-noreste se debe "andar hasta unas piedras muy grandes", piedras que el explorador Vallejo encontró sin dificultad: "vimos las piedras grandes i nos apeamos al pie de ellas. Mui cerca aparecía el zanjón que debíamos seguir sobre la derecha" (Vallejo

varilla grande, con la que se hace carbón, se da sobre los $3500 \mathrm{~m}$ de altura hasta los $4300 \mathrm{~m}$; y de ahí, de los 4300 tenemos la otra variedad que es la varilla de champa, que es una chatita. Toda se conoce que es varilla por el tipo de flor y la espina que tiene, y el olor también. Sobre los 4300 , donde no hay ninguna vegetación, ahí crece la champa" (Marco Bordones Segura, de Quebrada Paipote, septiembre de 1997).

12 Véase Carta geográfica Carrera Pinto 2700-6945 e Inca de Oro 2645-6945 escala 1: 50.000 del Instituto Geográfico Militar (IGM). Además, San Román (1896: 9, Tomo I) comenta que el llano de Varas también es conocido como Nangari.
1972: 34). En efecto, el derrotero de Fermín Guerra señala: "andarás a la derecha siguiendo un zanjón hasta dar con unas lomas de arena". El "zanjón" que se debe seguir es el lecho seco de escurrimiento espasmódico formado en miles de años que va remontando el Llano de Varas en dirección sur a norte. Desde las grandes piedras, siguiendo en dirección norte el "zanjón" del Llano de Varas, se sube suavemente en altura, y al final del "zanjón" se llega a las "lomas de arenas", otro de los hitos del derrotero de Tres Portezuelos. El escrito de Vallejo advierte que "el zanjón que nos guiaba se había borrado; pero mui a lo lejos i al frente veíamos dibujado el perfil de unas alturas que no podían ser sino las lomas buscadas" (Vallejo 1872: 34). Enseguida relata su llegada al lugar: "A pie i con mucha dificultad conseguimos trepar los cerros, porque la arena movediza de que se componen rodaba con nosotros a cada paso" (Vallejo 1872: 34-35). Estas lomas de arena seguramente se trataban de dos pequeños montículos de unos 50 a $100 \mathrm{~m}$ de elevación por sobre el llano, que 
se localizan al final del lecho que está marcado como escurrimiento del "zanjón".

Las "lomas de arena", en el derrotero de Fermín Guerra, constituyen un importante punto de observación de los cordones de cerros y de los Tres Portezuelos. Entre estos puntos no existen descripciones de otros hitos intermedios que suministren indicios de la geografía que va entre las lomas de arena y el punto observado, el cerro de Tres Portezuelos. El derrotero hace un silencio geográfico, parafraseando a Núñez y Santoro (1988). La única indicación sobre la observación geográfica y el rumbo del mineral de plata que se escribe en el derrotero es la siguiente: "Desde estas lomas descubrirás, mirando al lado del mar, un cordón de cerros i andarás hasta llegar al cordón dirigiéndote derecho a unos tres portezuelos que se ven desde muy lejos". Esta mirada desde la cumbre de la "loma de arena" es en dirección al noroeste, buscando otear un cordón de cerros con Tres Portezuelos "que se ven desde muy lejos". Se trataría de unos cerros ubicados al poniente, aproximadamente a 10 ó $15 \mathrm{~km}$ del punto de observación, cuya "cierta sombra o mancha que pegada a la tierra ofrecía un color más oscuro" (Vallejo 1872: 35). Estos cerros están en rumbo aproximado de $315^{\circ}$ observados desde la cima de las colinas de arena, y coinciden con los cerros denominados Tres Puntas. Estos cerros en la segunda mitad del siglo XIX darán origen al importante mineral de plata del mismo nombre. La indicación del derrotero para arribar al punto señalado sólo invita a caminar el trecho que falta teniendo como único faro este cordón de cerros más oscuros con "tres portezuelos" que se observan a lontananza: "i andarás hasta llegar al cordón dirigiéndote derecho a unos tres portezuelos que se ven desde muy lejos".

Asumiendo que el cordón de cerros oscuros con los tres portezuelos corresponde a los cerros de Tres Puntas -que efectivamente se divisan desde el punto de observación de las "lomas de arena"-, entonces la geografía que se debe cruzar con rumbo de 315 grados aproximadamente, corresponde a pequeñas depresiones desérticas que como pasadizos flanqueados por cerros bajos de pendientes suaves, se dirigen a modo de una larga quebrada hasta los cerros oscuros. Entre las "lomas de arena" y la dirección a Tres Portezuelos, se atraviesa los lugares denominados actualmente Buena Esperanza, Chimberos y se llega a

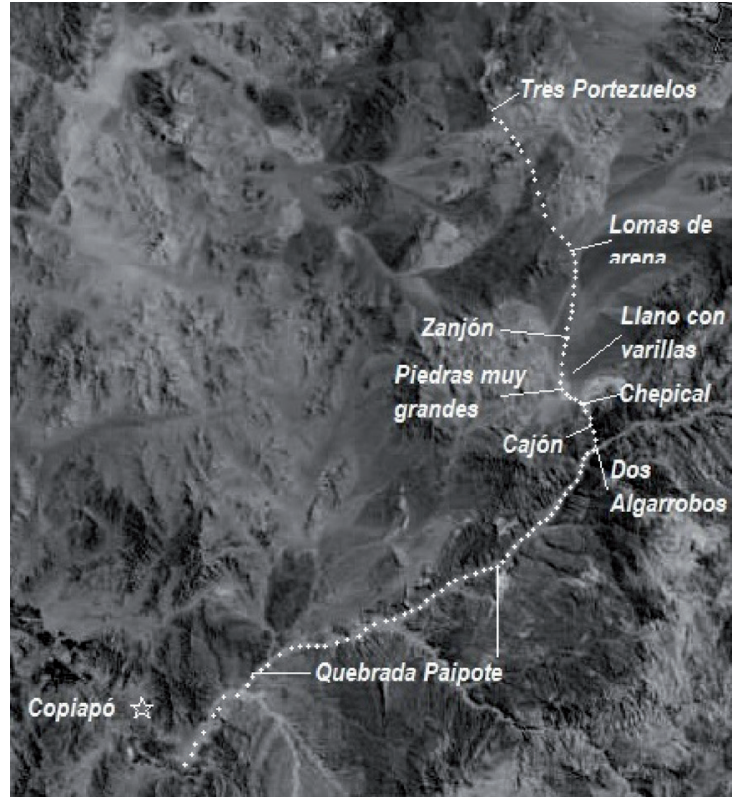

Figura 1. Mapa del Derrotero de Tres Portezuelos.

Tres Puntas. Allí se presenta de modo inconfundible el cordón de cerros oscuros con sus puntas y portezuelos.

Cuando ya hemos identificado los cerros correspondientes a los tres portezuelos, es preciso hacer un foco o close-up sobre detalles geográficos del lugar preciso donde se encuentra la veta. Estos deben leerse y observarse con ojos de minero y oficio de cateador. "En el (portezuelo) de tu izquierda, que subirás, encontraras una veta que la rumbearas a la derecha hasta dar con un picado de una vara de hondura y poco más allá está un crestón de plomería en el cual hai una cruz hecha con un cuchillo" (Vallejo 1878: 32). La descripción debe entenderse del siguiente modo. En el "portezuelo" de la izquierda del cordón o del cerro Tres Puntas, existe una "veta", un filón o franja de mineral que se intercala entre los estratos de la corteza del cerro. Es distinguible como una faja de color diferente al resto de la roca que la contiene. Ubicado el filón o veta, hay que seguir rumbo a la derecha o dirigirse en esa dirección para ubicar un "picado de una vara de hondura", entendiendo por esto una horadación en el suelo o en la roca realizado con herramientas mediante fuerza humana (picota, barreno, martillo y cincel), que posee una "hondura" o profundidad de 0.85 m, "una vara", y siguiendo la misma dirección -no señala cuantos pasos- aparecerá un "crestón de plomería en el cual hai una cruz hecha con un cuchillo". Éste es el 
objetivo, el término de la ruta, la estación terminal del derrotero. Para encontrar el "crestón de plomería" se debe considerar que un "crestón" es un filón o veta de mineral que aflora y sobresale sobre el terreno, y si es de "plomería" entonces "contiene plata nativa, sulfato y cloruro de plata" (Alonso 1995: 178). Allí está, y para que no exista duda, el derrotero de Fermín Guerra dice que tiene "una cruz marcada con cuchillo", la última señal ex profesa para encontrar la riqueza argentífera, a la que se arriba después de 86 kilómetros de navegación, e interpretando el derrotero de Tres Portezuelos, como una geográfica literaria, constatable en el paisaje y en el territorio (Figura 1).

\section{Descubrimiento de Tres Puntas}

Es probable que la publicación del derrotero de Tres Portezuelos el 22 de febrero de 1842, en el diario El Mercurio, alentara nuevas expediciones de cateo de minerales. Ayudó a las empresas de exploración a la reapertura de las minas de cobre de Puquios y la construcción del ferrocarril a mediados del siglo XIX, que atravesó la quebrada de Paipote hasta Puquios (Philippi F. 1975), lugar muy cercano al Chepical, punto importante de acceso al derrotero de Tres Portezuelos. También, el inicio de los cultivos por esos años en la Finca de Chañaral (Cervellino y Sills 2001) constituyó un punto de apoyo a los cateadores. Ambos lugares se convirtieron en zonas de abastecimiento de recursos para los mineros que escudriñaban la escondida veta. Muchas expediciones no tuvieron éxito: “...después de recorrer esas serranías procurando no apartarse mucho de las aguadas, ni de la finca (Chañaral), ni de las minas de cobre diseminadas en el desierto, y siempre con la huella de un camino a la vista a fin de no extraviarse, todos los cateadores que buscaban la riqueza de los Tres Portezuelos, llegaban trayendo solamente la relación de su penosa expedición, y sus animales y ellos mismos, bastante maltratados" (Sayago 1874: 393).

El acceso a Tres Portezuelos o Tres Puntas, no sólo se realizaba por la ruta descrita en el derrotero. Estaba también el Camino del Inca, que unía a Copiapó con la Finca de Chañaral, pasando por la base del cerro de Tres Puntas (Iribarren y Bergholz 1972, Sinclaire 2007). El camino incaico era traficado por pastores y cateadores, especialmente del Pueblo de Indios de San Fernando de Copiapó (Sayago 1874; Gigoux 1927; Molina 2010a). El lugar, a pesar de su aridez, en sus quebradas poseía cierta vegetación estacional y una aguada en los cerros de Tres Puntas, lo que favorecía el uso estacional y temporal en actividades de tránsito ganadero, caza y posiblemente explotación minera indígena. En efecto, el mismo derrotero de Fermín Guerra, al final del escrito, agrega dos datos geográficos muy interesantes que pueden asociarse al cerro de Tres Puntas: "Al pie del portezuelo del medio hai una buena aguada donde es mui fácil cazar huanacos i burros chúcaros" (Vallejo 1878, 33). Efectivamente, el cerro de Tres Puntas posee una de las escasas aguadas de la zona, que está ubicada en una de las quebradillas que bajan desde los portezuelos en dirección sureste. Se trata del agua de Tres Puntas, que sirvió al abastecimiento humano y abrevadero de animales, guanacos y burros salvajes. Estos últimos apartados de la manada o escapados de sus dueños que muy probablemente frecuentaron el área o zonas cercanas. Tres Puntas no era lugar desconocido para pastores y cateadores, especialmente del Pueblo de Indios de San Fernando de Copiapó, los que durante el siglo XIX se adentraban en el desierto llevando sus ganados hasta Doña Inés y la Encantada, más al norte de Tres Puntas y del río Salado (Sayago 1874; San Román 1896; Gigoux 1927; Molina 2010). Si los indígenas, preferentemente de apellidos Chillimacu, Alcota, Tacquia, entre otros, realizaban explotación de los minerales de platas, estás eran discretas, al margen del conocimiento público y alejado del interés, primero de españoles y luego de empresarios republicanos (Sayago 1874; Vicuña Mackenna 1882). El acceso a Tres Puntas desde Copiapó por el Camino del Inca era la vía más directa por el desierto de Atacama o Despoblado, ocupada desde períodos coloniales y prehispánicos. Efectivamente, el Camino del Inca pasaba en sentido norte-sur, por la base oriental de los cerros Tres Portezuelos o Tres Puntas. El lugar central de Tres Puntas se denominaba Placilla del Inca, era un promontorio que por su borde oriental cruzaba el camino incaico, pudiendo observarse su trazado en el Mapa del Mineral de Tres Puntas, confeccionado en 1921 (Greim 2008). No es de extrañar que al momento en que se produce el descubrimiento de las vetas de plata, aparezcan los indígenas como primeros mineros y cateadores, ya conocedores de esas riquezas (Gigoux 1927). ${ }^{13}$

13 En efecto el descubrimiento de las minas de plata Buena Esperan$z a$ en el sector Chimbero y la mina Al fin hallada en Tres Puntas, tenían evidencias de antiguos trabajos por parte de los indígenas del Pueblo de Indios de Copiapó: “...lo manifestaban varios 
El descubrimiento del mineral de plata de Tres Puntas y derrotero de Tres Portezuelos, se produce a mediados del siglo XIX. Los relatos poseen el sabor de la leyenda, pero son comprobables en las inscripciones de los pedimentos mineros y en las faenas extractivas que se instalan en el lugar. Se dice que un peón de minas de apellido Osorio en 1848 llegó a Copiapó desde El Salado, poblado y mina de la quebrada de Chañaral (Bowman 1924) y mostró piedras de plata sacadas de un crestón que había descubierto en el trayecto. Se dice que una mujer le embriagó y obtuvo el secreto de la ubicación del mineral (Sayago 1874). Otra versión asegura que la confesión fue realizada durante las celebraciones del 18 de Septiembre de 1848 (Philippi 1860). Cualquiera fuese el momento, un nuevo derrotero se escribía. "La riqueza había sido hallada, viniendo de las minas del Salado hacia la ciudad, en un cerro que quedaba un poco a la parte del mar, mirado desde el Bonete y junto al camino del Inca" (Sayago 1874: 393). Las señas eran coincidentes con las de Tres Portezuelos. La riqueza de plata estaba en un cerro junto al Camino del Inca. Para ubicar al cerro de las vetas de plata se debía mirar hacia el lado del mar desde el "cerro Bonete", ubicado en el Llano de Varas, en la misma longitud de las "lomas de arena", señaladas en el derrotero de Fermín Guerra, pero aproximadamente siete kilómetros al norte de estas. ${ }^{14}$ El "cerro Bonete" se eleva unos $400 \mathrm{~m}$ sobre el llano, y desde su cumbre la vista es inmejorable para buscar el cerro que tenía el filón de plata al lado del Camino del Inca: "El cerro bonete parecía ser la llave del derrotero" (Sayago 1874: 393).

En la búsqueda de cateadores del desierto que conocieran el cerro Bonete, apareció Vicente Domingo Garín,

escarpes y escombros de marai y herramientas encontradas al establecerse las pertenencias de Tres Puntas y también los restos de ranchos de indios de que hace referencia al pedimento de Chimbero. La india Chillimaco al saber el descubrimiento de Buena Esperanza, agregó de propia voluntad algunas demarcaciones de la veta, tales que encontrándoselas conforme con el terreno, se dedujo de allí que esa riqueza era una de las tantas arrancadas por la casualidad a la instintiva reserva de los indios" (Sayago 1874: 394-395). Otros autores coinciden en que las minas de plata eran conocidas y explotadas por indígenas, y que ello dio noticia del derrotero: "Fue la Chillimaca, esa vieja indígena, la que supo ver lo que nadie vió y decir que esas piedras oscuras, que estos crestones de roca negras, eran de plata pura que los siglos habían oxidado" (Gigoux 1927: 1081).

14 Véase Carta geográfica Inca de Oro, escala 1:50.000 del Instituto Geográfico Militar IGM. instruido del lugar por tener faenas mineras en la zona. Salieron de Copiapó, pero una segunda expedición les siguió el paso. Ninguna de ellas alojó en el cerro Bonete. La primera de éstas pernoctó en un cerro de enfrente, el 23 de septiembre de 1848: "José Guerra González, de la primera expedición, descubría la Buena Esperanza en el cerro que se ha llamado el Chimbero, por ser él y sus compañeros vecinos del barrio de la Chimba de esta ciudad -Copiapó-" (Sayago 1874:394). La segunda expedición, liderada por Mateo Pérez, fue a alojar una legua más al noreste de la primera. Siguió camino y "daba con el crestón de la Al fin hallada de la sierra de Tres Puntas, contigua al camino del Inca" (Sayago 1874, 394). Se produjeron dos descubrimientos de minerales de plata en un mismo momento. Mientras la mina de Buena Esperanza no tenía aparentemente un derrotero conocido, pero sí una explotación indígena previa, el descubrimiento de la mina Alfin hallada era simbólico y significativo. Su nombre denotaba algo buscado desde largo tiempo, que tenía a la base el derrotero de Tres Portezuelos desde 1792: “...no cabe disputa que la veta del burrero Fermín Guerra, revelada en la agonía de la muerte, sea la misma descubierta en el cerro de Tres Puntas", escribía el historiador Sayago (1874: 395). Es probable que sea la misma veta, pero localizada en un lugar distinto, pues la veta del derrotero de Fermín Guerra estaba en una de las quebradas que baja del cerro Tres Puntas, pero a pocos metros de la base de este promontorio, donde se encontró la mina Al fin hallada. El derrotero de Fermín Guerra había dado sus frutos, demostraba su veracidad y superaba la leyenda del derrotero perdido para transformarse en una cartografía de las ruta mineras que a través de una geografía literaria era capaz de describir el camino para alcanzar la veta de plata, tan buscada por mineros durante el siglo XIX (Figura 2).

\section{Epílogo del mineral de Tres Puntas}

Los cerros del derrotero de Tres Portezuelos fueron renombrados como Tres Puntas, más tarde “...llamadas San José, del Medio i Juana del Norte" (Espinoza 1897: 121). La zona se transformó en un importante distrito minero del siglo XIX y Tres Puntas creció rápidamente como un enclave que hizo florecer la actividad económica y social en el despoblado de Atacama. Rodulfo Philippi en su visita al mineral de plata en 1854, escribe cómo se otorgaban las propiedades mineras a los solicitantes. Al descubridor se le cedían dos pertenencias y una a los 


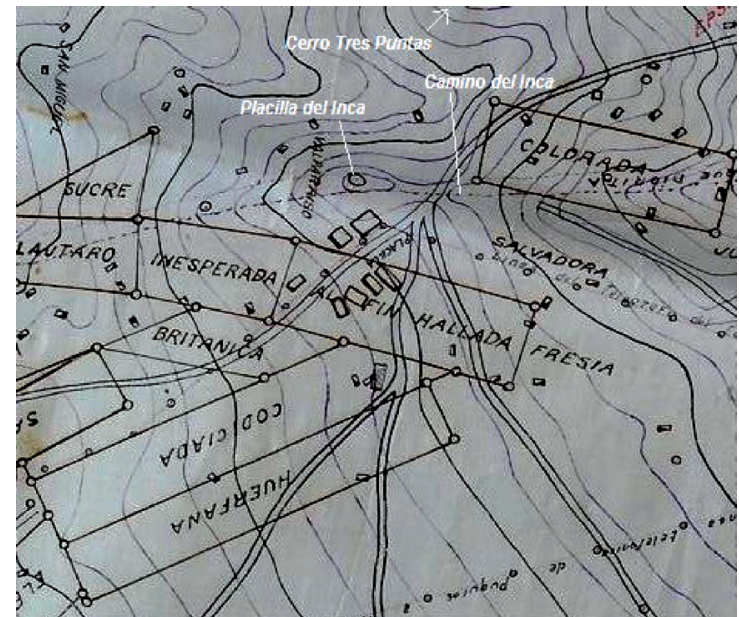

Figura 2. Fragmento del plano del mineral de Tres Puntas de 1921 (tomado de Greim 2008). Se observa la ubicación de la mina Al fin hallada, al pie del cerro de Tres Puntas. Además con línea blanca se indica el Camino del Inca y la Placilla del Inca.

posteriores denunciantes, siendo la superficie de la concesión reducida. Una "pertenencia tiene 200 varas de largo en la corrida de la veta" (Philippi 1860: 91), aproximadamente $168 \mathrm{~m}$ de largo. Estas concesiones permitían la cabida de numerosas explotaciones y la apertura de nuevas faenas mineras, atrayendo contingentes de mano de obra. "Muchísimas personas acudieron a la noticia de este descubrimiento de metales de una riqueza fabulosa para abrir minas en Trespuntas. Como por encanto nació un pueblo de 4000 almas en el desierto más árido que se pueda imaginar" (Philippi 1860: 91). ${ }^{15}$ A los primeros pedimentos en Tres Puntas se habían agregado muchos otros. "En el año 1851 se

15 A nivel regional también se potenció la actividad minera a través de los pedimentos: “...de 495 minas de plata denunciadas en Atacama en 1850, 381 fueron entre marzo y septiembre" (Bowman 1924: 74). En 1872, en el Departamento de Atacama existen "1.025 minas en actual trabajo, de las que 300 son de plata, 25 de oro i 700 de cobre" (Tornero 1872: 228) Vicente Pérez Rosales agrega que el impulso minero de mediados del siglo XIX estuvo ayudado también por el Estado de Chile “...el gobierno contribuyó poderosamente a favorecer este impulso [entre otras obras]... por el tratado concluido con el gobierno de la Confederación Argentina, el 30 de abril de 1856, el cual suprime todos los derechos de importación y exportación por la vía de la cordillera, entre las dos naciones. Este acto, cuya importancia es incalculable para Chile en general y para la provincia de Atacama en particular, va a contribuir de un modo muy eficaz a activar la explotación de las minas cuyo rendimiento no bastaba a cubrir los costos de extracción"(Pérez Rosales1986 [1857]: 277). trabajaban 49 minas, en 1953161 con 1724 mineros" (Philippi 1860: 91). Dos décadas después, el número había descendido ostensiblemente debido al broceo de algunas vetas, es decir, el término del mineral. En 1872, "constaba de 62 minas en el Distrito Minero que se extiende desde Tres Puntas a Chimbero (en la zona de la mina Buena esperanza)" (Tornero 1872: 230-231).

En estas minas se extraían en sus inicios "...metales finos, plata piña y relaves de plata. Los minerales más comunes son la plata nativa, el rosicler y los polísulfuros de plata", producción argentífera que generó importantes recursos financieros; “...no había más que tres que daban unas pingues ganancias, la Buena Esperanza, la Al fin hallada y la Salvadora" (Philippi 1860: 91), que corresponden a las primeras minas descubiertas. Ignacio Domeyko, en su visita a Tres Puntas en 1850, decía: "En estas minas de plata está la famosa veta La Esperanza, en cuyo patio de descarga un inmenso montón de plata roja (argent rouge) que contenía plata por valor de medio millón de francos; años hubo en que de esta sola mina se extraía anualmente 100.000 marcos de plata -un millón de francos-" (Domeyko 1978: 444).

En medio del trabajo, la riqueza y la abundancia, se desarrollaba la vida cotidiana de los mineros de Tres Puntas: "El pueblo tiene como 4.000 habitantes y las calles son regulares en las inmediaciones de la plaza", pero la destrucción era frecuente, pues "...ha sufrido cuatro incendios más o menos extensos en el corto período de su existencia", y "La sed del oro o más de la plata, la 'auri sacra fama' no ha permitido levantar siquiera una pequeña capilla, que recuerde a los vecinos el deber de adorar al Ser Supremo (sic)" (Philippi 1860: 90). Estos comentarios grafican una parte de la vida del asentamiento minero, donde lo laboral y lo social al parecer era febril (Figura 4).

La propiedad minera también sufrió cambios y transferencias. Algunos perdieron sus propiedades a manos de los prestamistas. “...Pedro Martínez, prototipo del pequeño y esforzado minero de plata y cobre, dueño de 2 y $1 / 2$ barras minas Al fin hallada" (Illanes 1992: 95), de Tres Puntas aparece como propietario en 1857, pero años más tarde la misma mina aparecerá inscrita a nombre de uno de los fundadores del Casa Bancaria Ossa y Escobar. La dueña de la mina Al fin hallada en 1872 era "la Testamentaria de J. 


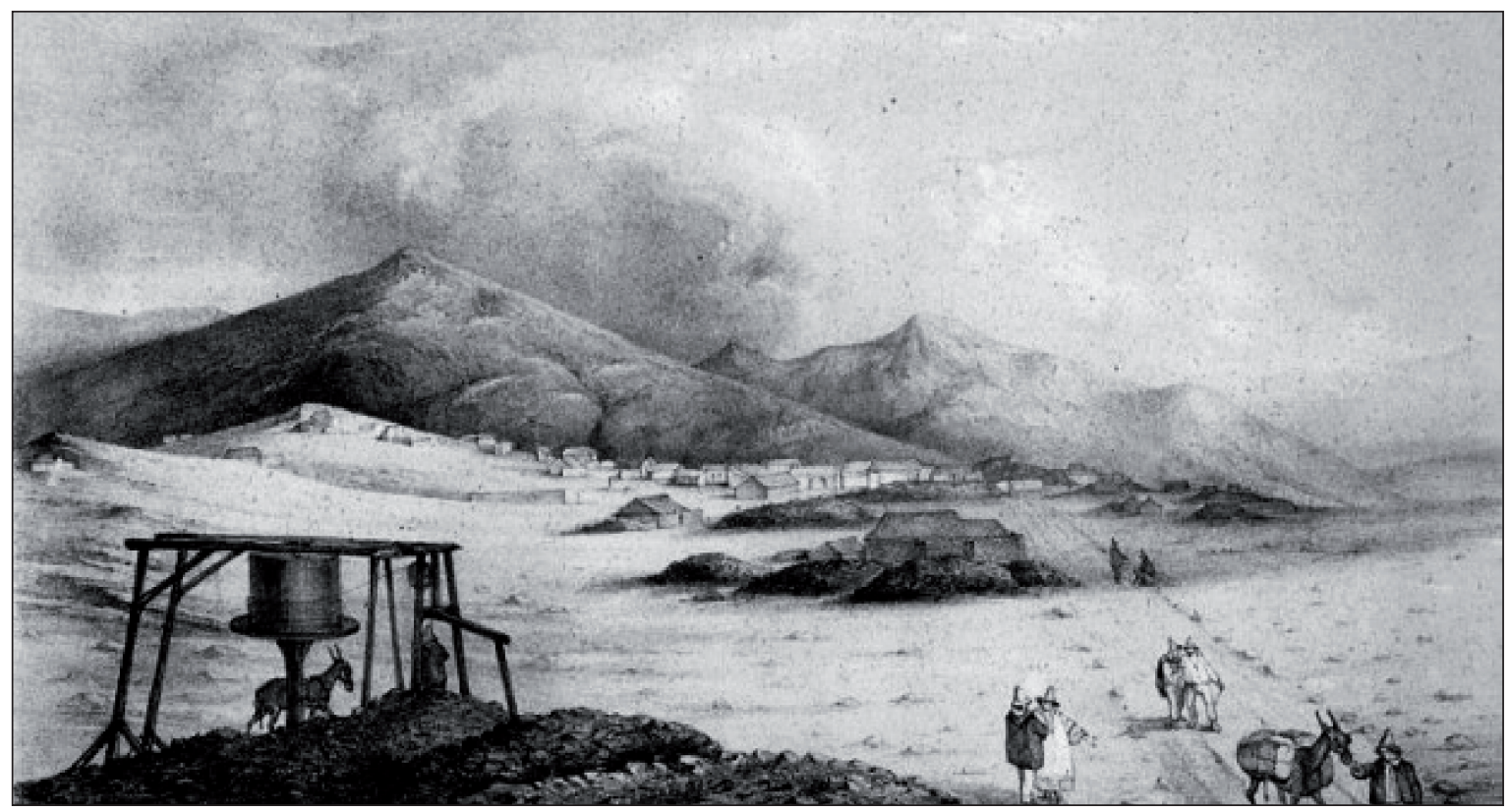

Figura 3. Tres Puntas en 1854 dibujado por Rodulfo Philippi.

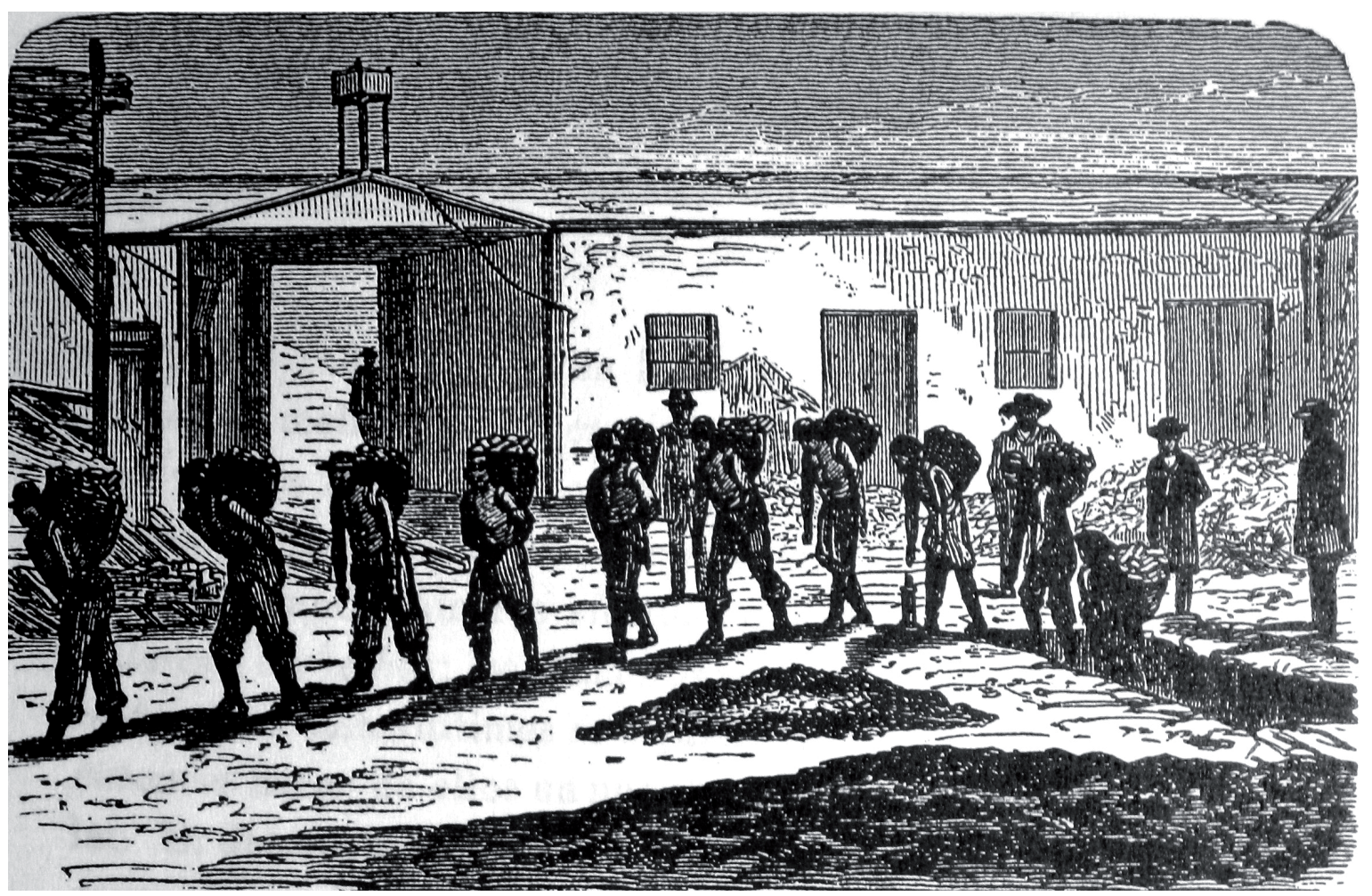

Figura 4. Tres Puntas. Apires de la mina Buena Esperanza (Tornero 1873). 
Ramón Ossa" (Tornero 1872: 230). ${ }^{16}$ Con los años la prosperidad también se fue opacando, reduciéndose el número de minas y de población. A fines del siglo XIX, Tres Puntas sólo tenía 280 habitantes y se le conocía con el nombre de "Pueblo del Inca, por hallarse sobre el Camino del Inca" (Espinoza 1897: 121).

\footnotetext{
$16 \mathrm{La}$ actividad minera no sólo se puede reconocer en el ámbito de la producción y explotación sino también en el financiero y especulativo. Los financistas que otorgaban créditos a los mineros amasaron grandes fortunas. La casa Bancaria Ossa y Escobar será una de las que adquiera varias minas como parte de lo que Illanes (1992) llama "dominación silenciosa". "Una de las más importantes relaciones crediticias en cuanto a obligación de producción minera, fue la que estableció por esos años (1857) con Pedro Martínez... del mineral de Tres Puntas" [...] "Ossa se convirtió así en uno de los acopiadores y exportadores de metales más importantes de la región. El año 1857, en una sola remesa a Swansca a la casa Gibbs e Hijos, Ossa envío 1.990 sacos de minerales de plata" (Illanes 1992: 95).
}

El mineral de Tres Puntas fue abandonado con la crisis económica mundial de 1929, que llevó los precios de la plata a valores antieconómicos, tendencia que se mantiene hasta la actualidad, cerrándose en la década de 1930 un importante ciclo minero en el desierto de Atacama. Esto generó el abandono de importantes faenas y enclaves que se localizaban en el desierto. El ciclo minero de la plata de Atacama tuvo entre uno de sus principales actores la búsqueda de derroteros, en este caso el de Tres Portezuelos.

Agradecimientos Parte de los resultados de este artículo fueron recabados en el desarrollo del Proyecto Fondecyt $\mathrm{N}^{\circ}$ 1040290, "El Despoblado de Atacama: Espacios, rutas, articulaciones y poblamiento en la región Circumpuneña". A Carole Sinclaire por sus aportes y sugerencias y a los evaluadores por sus comentarios críticos que ayudaron a mejorar el texto.

\section{* Referencias citadas}

ALONSO, R. 1995. Diccionario Minero. Glosario de voces utilizadas por los mineros de iberoamerica. Museo Nacional de Ciencias Naturales, Madrid.

BARTRA, R. 2004. El Salvaje Europeo. Centre de Cultura Contemporánea de Barcelona, Bancaja, Diputacío Barcelona Xarxa de Municipis, Barcelona.

BOIRA, J., 2012. Literatura y geografía se dan la mano. A propósito de la novela "El mapa y el territorio". Biblio $3 W$. Revista Bibliográfica de Geografía y Ciencias Sociales 995 (17). En línea: http://www. ub.es/geocrit/b3w-995.htm

BOWMAN, I. 1942 [1924]. Los senderos del Desierto de Atacama. Sociedad Chilena de Historia y Geografía, Santiago de Chile.

BRUNA, L. 2007. Historia de la Cartografía. Cartografía Historia de los mapas antiguos. En: http://valdeperrillos.com/books/cartografia-historia-mapas-antiguos

CERVELLINO, M. y N. SILLS. 2001. El arte rupestre de los sitios Finca de Chañaral y Quebrada de La Pinturas, Región de Atacama. En Segundas Jornadas de Arte y Arqueología. pp. 134-151. Museo Chileno de Arte Precolombino, Santiago de Chile.

DOMEYKO, I. 1978 [1962]. Mis Viajes:Memorias de un Exiliado. Tomo I. Ediciones de la Universidad de Chile, Santiago de Chile.
ECO, U. 2013. Historia de las tierras y los lugares legendarios. Editorial Lumen. España, Barcelona.

ESPINOZA, E. 1897. Jeografía Descriptiva de la República de Chile. Imprenta y Encuadernación Barcelona. Santiago de Chile.

FURLANI M. E. y M. GUTIÉRREZ DE MANCHÓN. 1990. Aportación al acercamiento entre literatura y geografía. Imágenes regionales de Mendoza (República Argentina). Revista de Geografía Norte Grande 17: 67-74.

GARCÍA, M. y R. CERAROLS. 2012. Geografías imaginarias del Marruecos colonial español: Las miradas de las viajeras. En Geografías de lo imaginario, A. Lindón y D. Hiernaux (Dir.), pp. 229243. Universidad Autonoma Metropolitana, Anthropos, Madrid.

GIGOUX, E. 1927. Notas, observaciones y recuerdos de los indígenas de Atacama. Revista Universitaria 8: 1077-1091.

GREIM, W. 2008 [1921]. Carta topográfica de las pertenencias mineras de Tres Puntas de F. del Puerto y Luis Ramírez. En: http://www.geovirtual.cl/minas/TresPuntas/Carta1921-oltotalesp.htm

HIERNAUX, D. y A. LINDÓN. 2012. Renovadas intersecciones: la espacialidad y lo imaginario. En Geografías de lo imaginario, A. Lindón y D. Hiernaux (Dir.), pp.9-28. Universidad Autónoma Metropolitana, Anthropos, Madrid. 
ILLANES M. A. 1992. La dominación silenciosa: productores y prestamistas en el minería de Atacama 1830-1860. Instituto Profesional de Estudios Superiores Blas Cañas, Santiago de Chile.

INSTITUTO GEOGRÁFICO MILITAR (IGM). 1973. Carta geográfica Carrera Pinto 2700-6945. IGM, Santiago de Chile.

INSTITUTO GEOGRÁFICO MILITAR (IGM). 1973. Carta geográfica Inca de Oro 2645-6945. IGM, Santiago de Chile.

IRIBARREN, J. y H. BERGHOLZ. 1972. El Camino del Inca en un sector del Norte Chico. En Actas del VI Congreso de Arqueología Chilena, pp. 229-266. Santiago.

KONIG, A. 1878. Introducción biográfica a Jotabeche. En Colección de los artículos de don J. Joaquín Vallejo, Publicados en varios periódicos bajo seudónimo de Jotabeche 1841-1847, pp. V-XXX. Imprenta del Deber, Valparaíso.

LE GOFF, J. 1996. Lo maravilloso y lo cotidiano en el occidente medieval. Gedisa, Barcelona.

MAGASICH, J.y J. M. DE BEER. 2001. América mágica: mitos y creencias en tiempos del descubrimiento del nuevo mundo. LOM ediciones. Santiago de Chile.

MOLINA, R. 2010. El desierto-despoblado de Atacama: geografía e imaginarios coloniales. Tesis de Magister en Geografía, Universidad de Chile, Santiago de Chile.

2010a. El Despoblado de Atacama: diversidad ambiental, evidencias históricas y etnográficas del poblamiento. En Actas XVII Congreso Nacional de Arqueología Chilena Valdivia 2006. Tomo 2: 1415-1428.

MOLINA, R., N. YÁÑEZ y D. PEÑA. 2001. Diagnóstico territorial Colla. Grupo de Investigación TEPU, para CONADI-Iquique. Ms. en poder del autor.

NIEMEYER, H. 1981. Descripción de la hoya hidrográfica del río Copiapó. Contribución Arqueológica 2: 27-141.

NÚÑEZ, L. y C. SANTORO. 1988. Cazadores de la puna seca y salada del área centro-sur Andina (Norte de Chile). Estudios Atacameños 9: 11-60.

PEDERSEN. H. 2012, Road-map to the Indian's Treasure. On the Chilean meteorite Vaca Muerta and its early mistake for silver Norderstedt. Edit. Book on Demand, Kabenhavn, Dinamarca.

PEREZ-ROSALES, V. 1986 [1857]. Ensayo sobre Chile. Ediciones de la Universidad de Chile, Santiago de Chile.
PHILIPPI, R. 1860. Viaje al Desierto de Atacama. Hecho de orden del Gobierno de Chile en el verano 1853-1854. Librería Eduardo Antón, Halle, Sajonia.

PHILIPPI, F. 1975. Viage de don Federico Philippi por el Desierto de Atacama en 1885. Revista Chilena de Historia y Geografía 143: 171-261.

PRATT, M. L. 2010. Ojos Imperiales: Literatura de Viajes y Transculturación. FCE, México DF.

RAE (Real Academia Española), 2001. Diccionario de la lengua española, $22^{a}$ edición. En: http://buscon.rae.es/

ROJAS MIX, M. 2006. El Imaginario; civilización y cultura del siglo XXI. Prometeo Libros, Buenos Aires.

SABATE-LLOBERA, N. 2007. Cuba como geografía literaria en la narrativa catalana contemporánea. University of Kentucky Doctoral Dissertations, paper 566. En http://uknowledge.uky.edu/gradschool_diss $/ 566$

SAN ROMÁN, F. 1896. Desierto y Cordilleras de Atacama. Tomos I y III. Imprenta Nacional, Santiago de Chile.

SAYAGO, C. M. 1874. Historia de Copiapó. Imprenta El Atacama, Copiapó.

SINCLAIRE, C. 2007. Ocupaciones prehispánicas e históricas en las rutas del Despoblado de Atacama. Informe Final, Sistematización arqueológica. Proyecto FONDECYT N 1040290. Ms.

TORNERO, R. 1873. Chile Ilustrado; Guía descriptivo del territorio de Chile, de las capitales de provincia i de puertos principales. Valparaíso, Chile.

TUAN Y. 2007. Topofilia. Editorial Melusina, España.

VALLEJO, J. J. 1878. Colección de los artículos de don J. Joaquín Vallejo, publicados en varios periódicos bajo seudónimo de Jotabeche 1841-1847. Imprenta del Deber, Valparaíso.

VALLEJO, J. J. 1970. Antología. Editorial Andrés Bello, Santiago de Chile.

VICUÑA MACKENNA, B. 1882. El libro de la plata. Imprenta Cervantes, Santiago de Chile.

VICUÑA, M. 1995. La imagen del desierto de Atacama (XVI-XIX). Editorial Universidad de Santiago, Santiago de Chile.

ZUSMAN, P. 2013. La geografía histórica, la imaginación y los imaginarios geográficos. Revista de Geografía Norte Grande 54: 51-66. 